\title{
Apresentação do Dossiê Temático Interfaces entre a Educação Especial e a Educação do Campo
}

A escolarização de camponeses com deficiência, transtornos do espectro autista e altas habilidades/superdotação passa a figurar, expressamente, na documentação político-normativa brasileira a partir dos anos 2000, defendendo o atendimento às especificidades socioculturais e às necessidades educacionais específicas dessa população.

Diante dos inúmeros desafios que emergem dos processos de implementação dessa proposta, quer pela complexidade político-pedagógica inerente ao tema, quer pelo histórico de descaso do poder público para com as populações com deficiência e campesinas, a comunidade científica passou a investigar esta problemática.

Nessa empreitada, destacamos, no Brasil, o pioneirismo do tratamento da temática por três pesquisadoras: na região Norte, a Prof ${ }^{\mathrm{a}}$. Dr ${ }^{\mathrm{a}}$. Ivanilde Apoluceno de Oliveira, da Universidade do Estado do Pará (UEPA), junto à Rede Educação Inclusiva na Amazônia; no Sudeste, a Prof ${ }^{a}$. Dr ${ }^{a}$. Katia Regina Moreno Caiado, da Universidade Federal de São Carlos (UFSCar), por meio do Núcleo de Estudos e Pesquisas em Direito à Educação - Educação Especial; e, no Centro-Oeste, a Prof ${ }^{a}$. Dra . Marilda Moraes Garcia Bruno, da Universidade Federal da Grande Dourados (UFGD), vinculada ao Grupo de Estudos e Pesquisa em Educação Inclusiva.

Além destas três precursoras, que, inclusive, configuram como autoras do presente dossiê, nos últimos anos, outros pesquisadores passaram a se debruçar sobre as relações entre a Educação Especial e a Educação do Campo, atentando-se à análise das políticas educacionais, da produção do conhecimento, dos atravessamentos identitários de seus públicos-alvo e dos diferentes contextos educativos que permeiam a construção dessas interfaces.

Em face desse movimento de construção, vislumbramos a importância de agrupar alguns indícios, pistas, desafios e possibilidades de interfaces entre a Educação Especial e a Educação do Campo. Nessa direção, apresentamos a proposta de um dossiê para a Comissão Editorial da Revista Interfaces da Educação, editada pelo Programa de Pós-Graduação em 
Educação da Universidade Estadual de Mato Grosso do Sul (UEMS) e cujo nome já sinaliza para o foco das contribuições publicadas.

Após a recepção da proposta pela Comissão Editorial, foi aberto edital para submissão de artigos relacionados às interfaces entre Educação Especial e Educação do Campo. Os textos enviados foram avaliados pelo sistema blind review, sendo que os aprovados integram esta coletânea.

O dossiê Interfaces entre a Educação Especial e a Educação do Campo é composto por 10 artigos de pesquisadores internacionais e nacionais, os quais oportunizam, a partir de variadas abordagens teóricometodológicas, a compreensão de múltiplas realidades que tangenciam os processos de inclusão/exclusão educacional dos estudantes com deficiência, transtornos do espectro autista e altas habilidades/superdotação que vivem e produzem sua existência no campo. Além dos artigos vinculados ao dossiê, também foi incorporado, por vias de fluxo contínuo do periódico, um artigo relacionado à Educação Especial.

Esperamos que o conjunto de textos aqui apresentado possa contribuir tanto para explicitar algumas das investigações produzidas sobre a interface Educação Especial - Educação do Campo, como para incitar a elaboração de outros estudos.

Boa leitura a tod@s!

Organizadores do Dossiê Temático Washington Cesar Shoiti Nozu Katia Regina Moreno Caiado Rodrigo Simão Camacho 